\title{
Evaluation of the antiviral and immunomodula- tory activity of nutritional supplement formula in a randomized, double-blind, placebo-controlled clinical trial
}

\author{
BOGDAN-DORIN ŞOLTUZU \\ ${ }^{1} \mathrm{PhD}$, University “Babeș-Bolyai”, Faculty of Biology and Geology, Cluj-Napoca, Romania
}

\begin{abstract}
Introduction: Sea buckthorn and bee products have a millennial tradition in oriental medicine, being used by Mongols, Tibetans, or Chinese both for the prevention and treatment of colds and increase the body immunity.

Objective: To evaluate the antiviral effect of a nutritional supplement formula based on sea buckthorn, honey, and propolis to reduce the incidence of respiratory viruses and the severity of their symptoms. Simultaneously, the aim was to evaluate this supplement formula's immunomodulatory activity on blood cell count (CBC) and on immunoglobulin A ( $\operatorname{IgA})$ level.

Subjects: A total of 50 volunteers, of whom 25 received a nutritional supplement formula based on sea buckthorn, honey, and propolis product at random, and 25 received a placebo product. The duration of the product administration was 30 days.

Results: The number of viral infections decreased statistically significantly $(p<0.05)$ in the group receiving the nutritional supplement formula based on sea buckthorn, honey, and propolis product SBHPG compared to the placebo group PG, reducing the relative risk of infection by $71.42 \%$. The immunomodulatory effect in SBHPG consisted of a statistically significant reduction in the number of neutrophils and monocytes and an increase in the number of lymphocytes than PG $(\mathrm{p}<0.05)$.

Conclusion: The nutritional supplement formula decreased respiratory viruses infections incidence and reduced the severity of the symptoms.
\end{abstract}

Keywords Supplement, Sea buckthorn, Honey, Propolis, Influenza, Coronavirus, Cell blood count.

To cite this article: ŞOLTUZU BD. Evaluation of the antiviral and immunomodulatory activity of nutritional supplement formula in a randomized, double-blind, placebo-controlled clinical trial. Rom Biotechnol Lett. 2021; 26(4): 2869-2878. DOI: 10.25083/rbl/26.4/2869-2878

7 *Corresponding author: BOGDAN-DORIN ŞOLTUZU, PhD, University "Babeș-Bolyai”, Faculty of Biology and Geology, Str. Republicii (Gh. Bilașcu) nr. 44, 400015, Cluj-Napoca, Romania E-mail: bogdansoltuzu@yahoo.ro Tel.:0749798917 


\section{Introduction}

Influenza, acute upper respiratory tract infections, and severe acute respiratory infections negatively impact the population, especially the elderly and people with various comorbidities. At present, there are few drugs against influenza and respiratory viruses, but the sensitivity of viral agents to these drugs decrease from year to year. At the same time, some antivirals may have unwanted side effects (CHOI et al, 2009, 2012).

Medicinal plants and bee products have a millennial tradition in traditional medicine, being used by various people to prevent or treat multiple pathologies. Both plants and hive products (honey, pasture, pollen, royal jelly, propolis) contain numerous nutrients and biologically active compounds that play a significant role in preventing and treating various viruses in humans and animals, without adverse effects of synthetic antivirals. Sea buckthorn (Hippophae rhamnoides L.) is a plant widespread in Mongolia, China, and Europe (ROUSI, 1971). Sea buckthorn has been used in traditional Tibetan, Chinese and Mongolian medicine (XU et al, 1994; YANG et al, 2000). The Tibetan doctor Yeshe Donden himself, the physician of Dalai Lama, described the medicinal importance of sea buckthorn in his works, listing its multiple therapeutic values such as fighting colds and exhaustion, fighting anemia increasing physical and mental endurance (SOLTUZU, 2018).

Honey and their bee products have been used since ancient times both as food and medicine for various diseases (MANYI-LOH et al, 2011). Propolis is a bee product made from vegetable resins. Bees use it to seal the hive and protect it from parasites, fungi, and bacteria. Propolis has been used in therapy since 300 BC by the Egyptians, Greeks, and Romans. In temperate climate areas worldwide, poplar bud exudates (especially Populus Nigra L.) are the primary source of resins collected by bees. Honey, propolis, pollen, royal jelly, and other bee products combined with various medicinal plants have been used since ancient times by the ancient Egyptians, Assyrians, Chinese, Greeks, Romans, and Arabs to treat infections and other ailments (MOLAN, 1999). Thanks to the knowledge acquired empirically from generation to generation over the millennia, several preparations are made based on bee products and buckthorn or other medicinal plants. In different combinations, they have curative effects in both colds and the case of seasonal flu. Although it enjoys high popularity among the population, there are very few clinical studies that scientifically prove the effectiveness of these natural remedies in preventing respiratory viruses.
The main objective of this study was to evaluate the antiviral effect of a nutritional supplement formula based on sea buckthorn, honey, and propolis on reducing the incidence of respiratory viruses infections (influenza, acute upper respiratory tract infections, and severe acute respiratory infections) and/or reducing the severity of their symptoms. The secondary objective was to evaluate this supplement formula's immunomodulatory activity on blood cell count and immunoglobulin A ( $\operatorname{IgA}$ ) level.

\section{Participants and Methods}

\section{Study participants}

The present study participants were males and females aged between 18 and 70, recruited through announcements made on social networks and through a local radio station. Information from participants on lifestyle and eating habits was collected using the questionnaire method. Study participants were informed about the working protocol using a group created on Facebook and other social networks. Following the information, the participants gave their consent to the procedure. The exclusion criteria from the study were: influenza vaccination made in the last half-year, medication with anticoagulants (warfarin, heparin), treatment with immunosuppressants, allergy to bee products, BMI $<18$ or $>40$, refusal to stop consuming in the period of study sea buckthorn, honey, propolis, probiotics or inadequate storage conditions of the product during administration.

Randomization of participants was done in a double-blind manner (Figure 1). Layered randomization was conducted using stratification of the following characteristics: age, sex, body mass index (BMI), smoking and alcohol consumption habits, consumption of fruits and vegetables, level of physical activity, use of vitamin or mineral supplements, frequency of protection means use (mask, gloves, disinfectants), the incidence of respiratory viruses in previous years.

Randomization was performed based on letter codes using an online random number generator.

\section{Study design}

The study was conducted in Iasi and was designed as a standard model in clinical trials (randomized, double-blind, and placebo-controlled). During the two months of observation (November, December), participants were instructed to monitor their respiratory virusspecific symptoms daily and report their severity using a questionnaire with four response options: not at all, mild, moderate, severe. Blood samples were taken at the beginning and end of the product administration period 
for laboratory analysis of the complete blood count and quantitative dosing of serum immunoglobulin $\mathrm{A}(\operatorname{Ig} \mathrm{A})$. After completing the questionnaire on lifestyle and taking blood samples for laboratory tests, one group of participants (SBHPG) received the product verum. The other group (PG) received an experimental placebo product with a similar appearance, taste, and odor. Both verum and placebo were bottled in $500 \mathrm{ml}$ plastic bottles and labeled with instructions for use. During the product administration, participants were advised to keep the product in the refrigerator at a temperature of $3-4^{\circ} \mathrm{C}$. Each participant had to administer the product on an empty stomach every morning. To see if participants realized whether they received the verum or placebo product, each of them was asked, at the end of the study, to guess which product they received, confirming or refuting them if they guessed correctly. Following the product's administration, participants received a questionnaire in which they were asked if the product received had other effects on the body (influence on appetite, weight, and energy level). At the same time, they were asked if the product positively impacted their lives or if they felt any side effects. At the end of the study, the correspondence between each participant's letter code and the randomly assigned number on each product was declassified. It should be noted that during the study, participants took their prescribed medications as well as supplements (where appropriate), with the recommendation not to exceed daily doses. Participants were not allowed to consume sea buckthorn, honey, or products containing sea buckthorn, propolis, or probiotics.

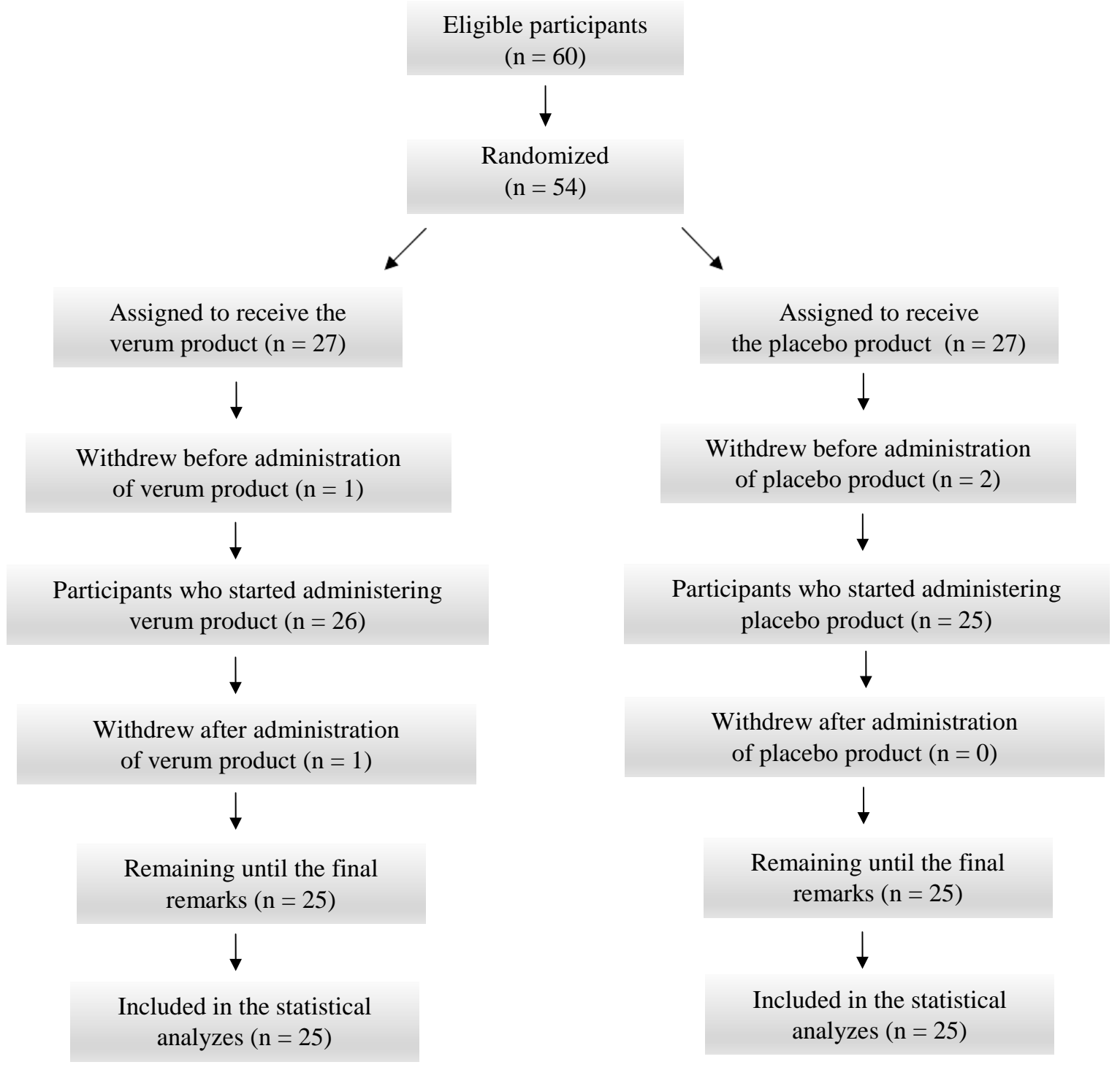

Figure 1. Dynamics of participants enrolled in the study 
Respiratory viruses are classified into three groups, depending on their seasonal epidemics. Influenza virus, human coronavirus ( $\mathrm{HCoV}$ ) (such as strains OC43, HKU1, 229E, and NL63), and human respiratory syncytial virus (RSV) shows peaks in winter. Adenovirus, human bocavirus (HBoV), influenza virus (PIV), human metapneumovirus (hMPV), and rhinovirus can be detected throughout the year. Seasonal patterns of parainfluenza viruses (PIV) are specific to their strains. Peak epidemics with type 1 PIV (PIV1) occur in autumn and type 3 PIV (PIV3) in spring-summer. The prevalence of non-rhinovirus enteroviruses increases in summer (MORIYAMA et al, 2020). Coronaviruses, the etiological agents of common colds and flu viruses, cause infections among the population, usually in late autumn and in the winter (PUHAKKA et al, 2000). At the end of 2019, the SARSCov2 virus also appeared in the Chinese city of Wuhan, a coronavirus with a high transmission rate that caused the COVID 19 pandemic (PARASKEVIS et al, 2020). Cov2 SARS infection in Romania was reported on February 26, 2020, by confirmation of the first patient by RT-PCR technique (INSP).

Study participants began taking verum or placebo in mid-November for 30 days. Still, observations on the incidence and symptoms of viruses were made by the end of December because the nutritional supplement was considered a bioactive activity post-administration. Reporting the incidence of viruses and the severity of symptoms was performed using an adaptation of the Common Cold Unit questionnaire (JACKSON et al, 2004). The questionnaire considered five types of symptoms: general (fever, chills, muscle aches, headache), nasal (rhinorrhea, sneezing), eye (tear), throat (sore throat, cough), and thoracic (pain in the chest) or "others" where the participant had to specify the symptom. The severity of the symptoms was noted using a 4-step scale: no-0, mild-1, moderate-2, or severe-3, which gave a total score of 30. Participants were classified as not having a viral infection (if they did not have had symptoms), a possible viral infection (if they had one of the five types of mild symptoms plus cough), and probable infection (if there were moderate symptoms in at least two of the five types of symptoms or mild symptoms in 3 of the 5 categories) (JACKSON and et al, 2004). A participant could be considered to have a probable or possible viral infection if they reported symptoms for a day or more. Each day, the participant had to record if he had one or more specific symptoms for the symptoms' duration. If participants reported probable or possible viral infections, they were given rapid Vivadiag antigen tests for Covid $19+$ Influenza virus $A+$ Influenza virus $B$ in the first 3-7 days after the onset of specific symptoms. The first week of the observation period was excluded from the analysis to consider the virus's incubation period (PUHAKKA et al, 2000).

\section{Statistical analyzes}

Statistical analyzes were performed using Microsoft Office® Excel software and IBM® SPSS Statistics 22.0. The results were analyzed using the chi-square test for proportions and the Student t-test for quantitative variables at a probability of $99.95 \%$. The data obtained were expressed as mean \pm standard deviation. The estimated relative risk reduction (RRR) for infections or symptoms was calculated by comparing the group that received the verum product (SBHPG) with the group that received the placebo product $(\mathrm{PG})$. A relative risk value $<1$ means a decreased risk in the SBHPG.

\section{Laboratory methods}

Blood cell count (BCC-Test) and the blood level measures of immunoglobulin A ( $\operatorname{Ig} \mathrm{A})$ were performed at Praxis Laboratory (Iași, Romania). The blood cell count (BCC-Test) was performed using the Sysmex XT 1800 automatic analyzer by the fluorescence flow cytometry method using laser semiconductor and hydrodynamic focusing. Measures of immunoglobulin A (serum IgA) were performed using the Imola RX automated analyzer by the turbidimetry method. Influenza A or B and SARS-Cov2 virus infection testing was performed using Vivadiag rapid antigen tests for Covid 19, Influenza A virus, and Infleenza B virus.

\section{Obtaining the nutritional supplement formula \\ Obtaining raw sea buckthorn juice}

The sea buckthorn fruits used came from the species H. rhamnoides, ssp. Carpatica, Șerpeni variety, Pitești 1 and Pitești 2. The fruits were harvested in autumn 2020 from the municipality of Iași and stored in a frozen state. The fruits were thawed, washed, crushed in a fruit mill (blender), and strained through a sieve with a diameter starting from $2 \mathrm{~mm}$ and ending with a diameter of $0.8-0.1 \mathrm{~mm}$. The last sieve has the role of retaining the seeds and the fruit's epicarp that can extract sea buckthorn oil. The puree remaining after filtration was allowed to stand for 1-3 hours and then centrifuged for 15 minutes at a temperature of $4^{\circ} \mathrm{C}$. By centrifugation, the sea buckthorn juice was separated from the pasty layer of sediment. Sea buckthorn juice is relatively cloudy, depending on the number of suspended solids remaining after the centrifugation (BOCK et al. 1990; HEILSCHER and LORBER, 1996).

\section{Acacia honey}

Acacia honey was collected in the spring of 2020 and stored in appropriate containers specific for bee products storage. The choice of acacia honey was due to its empirically proven effectiveness in preventing and combating influenza and common colds and its hypoallergenic properties due to its low pollen content (MOHAMMED et al, 2018). 


\section{Obtaining propolis extract}

Propolis was collected in the autumn of 2020 and stored in appropriate containers specific for bee products storage. The propolis extract was made according to the protocol developed by Boeru and Derevici in 1978, with minor modifications. The crude propolis was cut and grounded using a pestle mortar. The propolis extract was performed using 95\% ethanol in a 1: 5 ratio for ten days in the dark with continuous stirring (100 rpm). After ten days, the mixture was filtered using Whatman chromatographic paper. The crude propolis extract was concentrated by evaporating the ethanol using a rotary evaporator under vacuum (RE-52CS) set at $50^{\circ} \mathrm{C}$ and $100 \mathrm{hPa}$

\section{Obtaining sea buckthorn leaf extract}

The sea buckthorn fruits used came from the species H. rhamnoides, ssp. Carpatica, the variety Șerpeni, Pitești 1, and Pitești 2. The leaves were harvested in the fall of 2020 from the area of Iași. After that, they were dried naturally in hot air currents. For the extract's preparation, the sea buckthorn leaves were cut and grounded using a pestle mortar. The leaf extract was performed using ethanol $70 \%$ time, in a ratio of $1: 5$, for ten days in the dark, with continuous stirring $(100 \mathrm{rpm})$. After ten days, the mixture was filtered using Whatman chromatographic paper. Subsequently, the extract was concentrated by evaporating the ethanol using a rotary evaporator under vacuum (RE-52CS) set at $50^{\circ} \mathrm{C}$ and $100 \mathrm{hPa}$.

\section{Obtaining the nutritional supplement formula}

There is evidence that vitamin $\mathrm{C}$ and quercetin co-administration exerts a synergistic antiviral action due to overlapping antiviral and immunomodulatory properties and the capacity of ascorbate to recycle quercetin, increasing its efficacy. (BIANCATELLI et al, 2020).

Sea buckthorn juice has an average ascorbic acid content of $400 \mathrm{mg} / 100 \mathrm{~g}$, and acacia honey an average of $100 \mathrm{mg} / 100 \mathrm{~g}$ (DOBRINAS et al, 2006; GUTZEIT et al, 2008). To obtain the synergistic effect of flavonoids and vitamin $\mathrm{C}$, raw sea buckthorn juice and acacia honey were mixed with the flavonoid-rich extracts of sea buckthorn leaves and propolis in a nutritional supplement formula with a daily dosage of bioactive compounds as described in Table 1. In addition to the reason related to synergy, opting for this formula was that due to the high content of ascorbic acid and organic acids, the taste of sea buckthorn juice does not always attract consumers. When mixed with honey, the taste of the product became more balanced and much more pleasant.

\section{Obtaining the placebo product}

The experimental placebo product looked, tasted, and smelled similar to the verum product. It was made from a mixture of water, concentrated orange syrup, commercial grapefruit concentrated syrup, and a sweetener. After preparation, the product was bottled in labeled $500 \mathrm{ml}$ vials and refrigerated at a temperature of $3-4^{\circ} \mathrm{C}$.

Table 1. Daily dosage of bioactive compounds in the supplement formula

\begin{tabular}{|l|l|}
\hline Bioactive compounds & Mg \\
\hline Vitamin C & 125.5 \\
\hline Propolis extract & 250 \\
\hline Sea buckthorn leaf extract & 250 \\
\hline
\end{tabular}

\section{Results}

\section{Participants}

Randomized participants from the two groups SBHPG and PG, had relatively similar characteristics, without significant differences in: age, sex, BMI, eating habits, smoking and alcohol consumption, physical activity level, and frequency of use, means of protection (mask, gloves, and disinfectants) and the incidence of respiratory viruses in previous seasons (Table 2). It should be noted that $7.5 \%$ of participants dropped out of the study before being randomized into the two groups SBHPG and PG. After randomization, $5.5 \%$ withdrew before receiving verum or placebo and $1.8 \%$ after receiving it (Figure 1). After receipt of the product, the reason for withdrawal was related to the inadequate temperature conditions at which it was stored. After declassifying the study groups,
$68 \%$ of SBHPG participants correctly guessed the product and $48 \%$ of PG participants. Following the completed questionnaire analysis, at the end of the observation phase, in the SBHPG group, $28 \%$ reported that the product increased their appetite, $4 \%$ that it reduced their body weight, and $56 \%$ felt fuller of energy. At the same time, $96 \%$ considered that the product has a pleasant taste, and $88 \%$ that it positively impacted their lives. No SBHPG participants showed any adverse effects following the administration of the product. In the PG group, $15 \%$ reported that the product increased their appetite, no one reported a reduction in body weight, and $20 \%$ felt fuller of energy. At the same time, all participants considered that the product has a pleasant taste, and $56 \%$ positively impacted their lives. No participant in the PG group showed any adverse effects following the administration of the product. 
Table 2. Profile of participants

\begin{tabular}{|c|c|c|}
\hline Characteristics & SBHPG, no (\%) & PG, no (\%) \\
\hline Females & $17(68)$ & $17(68)$ \\
\hline Males & $8(32)$ & $8(32)$ \\
\hline \multicolumn{3}{|l|}{ Age (years) } \\
\hline $18-40$ & $11(44)$ & $11(44)$ \\
\hline $40-65$ & $9(36)$ & $9(36)$ \\
\hline$>65$ & $5(20)$ & $5(20)$ \\
\hline Smoking & $7(28)$ & $6(24)$ \\
\hline \multicolumn{3}{|l|}{ Consumption of alcoholic beverages } \\
\hline Not & $6(24)$ & $5(20$ \\
\hline Rarely & $15(60)$ & $18(72$ \\
\hline Frequently & $4(16)$ & $2(8)$ \\
\hline Consumption of nutritional supplements & $14(56)$ & $13(52)$ \\
\hline \multicolumn{3}{|l|}{ Physical activity } \\
\hline Not at all & $9(36)$ & $10(40)$ \\
\hline 1-3 times a week & $10(40)$ & $12(48)$ \\
\hline$>3$ times a week & $6(24)$ & $3(12)$ \\
\hline \multicolumn{3}{|l|}{ Weekly fruist consumption } \\
\hline Not at all & $0(0)$ & $0(0)$ \\
\hline More than once & $14(56)$ & $17(68)$ \\
\hline Daily & $11(44)$ & $8(32)$ \\
\hline \multicolumn{3}{|l|}{ Weekly vegetable consumption } \\
\hline Not at all & $0(0)$ & $0(0)$ \\
\hline More than once & $15(60)$ & $14(56)$ \\
\hline Daily & $10(40)$ & $11(44)$ \\
\hline \multicolumn{3}{|l|}{ Use of protective equipment } \\
\hline Rarely & $6(24)$ & $5(20)$ \\
\hline Occasional & $8(32)$ & $10(40)$ \\
\hline Frequently & $11(44)$ & $10(40)$ \\
\hline \multicolumn{3}{|l|}{ Incidence of respiratory viruses infections } \\
\hline One time & $14(56)$ & $17(68)$ \\
\hline $2-3$ times & $9(36)$ & $8(32)$ \\
\hline$>2-3$ times & $2(8)$ & $0(0)$ \\
\hline $\begin{array}{l}\text { Severity score of respiratory virus symptoms } \\
\text { in previous seasons (Max score-30) }\end{array}$ & $11,6(38,6)$ & $11,08(36,93)$ \\
\hline
\end{tabular}

\section{Number of respiratory viruses infections}

The verum product administration reduced the relative reduction of the risk of infection by $71.42 \%$ (with a margin of confidence of $99.95 \%$ ) (Table 3). Following the performance of Vivadiag rapid antigenic tests on participants with possible and probable infections, was found 2 cases of Sars-Cov2 infection in the PG. The remaining cases of infection were most likely common colds caused by various strains of coronaviruses.

Table 3. Number of respiratory viral infections

\begin{tabular}{|l|c|c|c|}
\hline Number of viral infections & SBHPG & PG & RRR* \\
\hline Total number of infections n (\%) & $2(8)$ & $7(28)$ & 71.42 \\
\hline Number of possible infections, n (\%) & $1(4)$ & - & \\
\hline Number of probable infections, n (\%) & $1(4)$ & $7(28)$ & \\
\hline Number of Influenza Virus type A infections n (\%) & - & - & \\
\hline Number of Influenza Virus type B infections n (\%) & - & - & \\
\hline Number of SarsCov2 infections (\%) & - & $2(8)$ & \\
\hline
\end{tabular}

Abbreviations: SBHPG - The group of participants received the nutritional supplement formula based on sea buckthorn, honey, and propolis; $\mathrm{PG}$ - Placebo group;

a25 of participants in SBHPG and 25 participants in PG;

${ }^{\mathrm{b}}$ The total score of symptoms is 30 ;

${ }^{\mathrm{c}} \mathrm{RRR}$-Relative risk reduction. 


\section{Severity of symptoms}

The verum product administration had the effect of reducing the severity of respiratory viruses symptoms $(\mathrm{p}<0.003)$. The symptom scores in SBHPG were 3 $(10 \%)$ and in PG 10.57 (35.2\%) out of 30 (total symptom severity score) (Table 4).

Table 4. Severity of symptoms

\begin{tabular}{|c|c|c|c|}
\hline Parameter & SBHPG & PG & P Value* \\
\hline Symptom score, $(\% \text { of total score) })^{\mathrm{a}}$ & $3(10)$ & $10.57(35.2)$ & 0.003 \\
\hline
\end{tabular}

Abbreviations: SBHPG - The group of participants received the nutritional supplement formula based on sea buckthorn, honey, and propolis; PG - Placebo group;

${ }^{a}$ The values represent the arithmetic averages of the participants' symptom scores. The total score of symptoms is 30 ;

*Significant difference $(\mathrm{P}<0.05)$ between SBHPG and PG.

\section{Blood cell count (BCC-Test)}

The effects of the verum product on the blood count are summarized in Table 5. A decrease in the total number of leukocytes $(p \leq 0.05)$ was found in SBHPG compared to PG. Of these, neutrophils and monocytes showed a significant reduction in SBHPG than in PG, and lymphocytes increased. Euzinophils did not show statistically significant changes $(p>0.05)$, and the number of basophils remained constant. Simultaneously, changes in the number of erythrocytes, platelets, and hemoglobin did not change significantly in SBHPG than PG $(\mathrm{p}>0.05)$.

\section{Immunoglobulin A (IgA)}

The effect of the verum product on the amount of $\operatorname{IgA}$ is summarized in Table 6 . There was no significant change in its amount in SBHPG compared to PG $(\mathrm{p}>0.05)$.

Table 5. Effects of the nutritional supplement formula on blood cell count (BCC) and immunoglobulin A (IgA)

\begin{tabular}{|c|c|c|c|c|c|c|}
\hline \multirow[t]{2}{*}{ Parameter } & \multicolumn{2}{|c|}{ SBHPG } & \multicolumn{2}{|c|}{ PG } & \multirow{2}{*}{$\begin{array}{l}\text { Difference } \\
\text { in change }\end{array}$} & \multirow{2}{*}{$\begin{array}{c}\mathbf{P} \\
\text { Value* }^{*}\end{array}$} \\
\hline & Baseline $^{a}$ & $\begin{array}{c}\text { After } 30 \\
\text { days - } \\
\text { Baseline }\end{array}$ & Baseline $^{a}$ & $\begin{array}{c}\text { After } 30 \\
\text { days - } \\
\text { Baseline }\end{array}$ & & \\
\hline $\begin{array}{l}\text { Erythrocytes } \\
\left(10^{6} / \mathrm{uL}\right)\end{array}$ & $4.72 \pm 0.47$ & -0.012 & $4.84 \pm 0.6$ & 0.04 & 0.08 & 0.47 \\
\hline $\begin{array}{l}\text { Hemoglobin } \\
(\mathrm{g} / \mathrm{dL})\end{array}$ & $13.78 \pm 1.56$ & 0.02 & $14.01 \pm 1.34$ & 0.13 & 0.15 & 0.51 \\
\hline $\begin{array}{l}\text { Total leukocyte } \\
\text { count }\left(10^{3} / \mathrm{uL}\right)\end{array}$ & $7.28 \pm 2.16$ & -0.88 & $5.43 \pm 2.10$ & 0.16 & -0.72 & $0.01 *$ \\
\hline $\begin{array}{l}\text { Neutrophils } \\
\left(10^{3} / \mathrm{uL}\right)\end{array}$ & $4.28 \pm 1.8$ & -0.71 & $4.31 \pm 1.3$ & -0.06 & -0.76 & $0.03 *$ \\
\hline $\begin{array}{l}\text { Monocytes } \\
\left(10^{3} / \mathrm{uL}\right)\end{array}$ & $0.59 \pm 0.24$ & -0.11 & $0.62 \pm 0.47$ & 0.07 & -0.04 & $0.04 *$ \\
\hline $\begin{array}{l}\text { Lymphocytes } \\
\left(10^{3} / \mathrm{uL}\right)\end{array}$ & $2.21 \pm 0.5$ & -0.10 & $0.62 \pm 0.75$ & 0.16 & 0.06 & $0.05^{*}$ \\
\hline $\begin{array}{l}\text { Eusinophils } \\
\left(10^{3} / \mathrm{uL}\right)\end{array}$ & $0.18 \pm 0.09$ & 0.02 & $2.21 \pm 0.09$ & 0.12 & 0.14 & 0.27 \\
\hline $\begin{array}{l}\text { Basophils } \\
\left(10^{3} / \mathrm{uL}\right)\end{array}$ & $0.04 \pm 0.1$ & - & $0.19 \pm 0.9$ & - & - & 0.32 \\
\hline $\operatorname{IgA}(\mathrm{mg} / \mathrm{dl})$ & $238.56 \pm 78$ & 1.33 & $0.05 \pm 75$ & -14.4 & -13.4 & 0.18 \\
\hline
\end{tabular}

Abbreviations: SBHPG - The group of participants received the nutritional supplement formula based on sea buckthorn, honey, and propolis; PG - Placebo Group;

aThe values represent the arithmetic means of the values of the parameters of the participants' blood tests;

*Significant difference $(\mathrm{P}<0.05)$ between SBHPG and PG.

\section{Discussions}

Participants in the present study were adults with a relatively healthy lifestyle, most physically active, mostly non-smokers, and occasional alcoholics. Regarding the incidence of respiratory viruses and their symptoms in previous seasons, there were no significant variations between SBHPG and PG. The frequency with which they used protection (disinfectants, gloves, masks) was relatively similar during the study. In terms of eating 
habits, the two groups were sufficiently homogeneous, in the sense that participants from both groups introduced into the diet approximately the same amounts of vitamins, minerals, and flavonoids.

The decrease in the number of respiratory viruses in the group of participants who received the verum product and the reduction in the severity of symptoms compared to the group that received the placebo product indicate a synergistic effect of the bioactive compounds of this nutritional supplement formula. A possible synergism is due to the potentiation of the antiviral effect of flavonoids by the high content of vitamin $\mathrm{C}$ in raw sea buckthorn juice. At the same time, vitamin $\mathrm{C}$ prevents the spontaneous degradation of flavonoids, requiring a concomitant administration to exert its antiviral effect (VRIJSEN et al, 1987). Results similar to those obtained in the present study were obtained by Cohen et al. in a randomized, double-blind, placebo-controlled study in children given an herbal preparation (Chizukit) containing $50 \mathrm{mg} / \mathrm{ml}$ echinacea, $50 \mathrm{mg} / \mathrm{ml}$ propolis, and $10 \mathrm{mg} / \mathrm{ml}$ vitamin $\mathrm{C}$ 3 months to children. The authors found a reduction in the number of respiratory infections and their symptoms (2004). However, these results contradict the results reported by Larmo et al. in a double-blind, randomized, placebo-controlled study of 233 adult participants who received $28 \mathrm{~g}$ of sea buckthorn puree daily for three months. At the end of the study, the authors did not report significant differences in common cold cases in the study group than the placebo group (2008). One possible explanation would be that the authors administered only a puree of sea buckthorn to the participants and not a mixture of ingredients with synergistic potential where bioactive compounds potentiate each other. Another explanation could be the small amount of product administered to the participants, an aspect mentioned at the end of the study even by the authors themselves.

It is essential to mention, however, some limitations of the present study. First, the determination of infections was based on a self-assessment of symptoms by participants. Although it is quite often used in clinical trials, it makes the diagnosis of respiratory viruses relatively subjective (TURNER et al, 2004). Even if possible or probable infections have been reported, and rapid tests have been performed, the chances are that they have been false positive for Sars-Cov2 virus infection (ARMSTRONG, 2020). Another aspect would be the fact that the study was carried out over a short period and, in most cases, in the case of a natural product, a long period of administration is needed for a more substantial effect. At the same time, it should be mentioned that, after declassifying the study groups, more than half of the SBHPG participants guessed that they had received the verum product. Thus there are also the premises of a placebo effect. Although it is an experimental protocol frequently used in clinical trials, there is still some controversy over how ideally it can be achieved to have optimal results (DESBIENS, 2002).
The immunomodulatory and anti-inflammatory properties of propolis and sea buckthorn are attributed to flavonoids and phenolic acids. These bioactive compounds activate the immune cells involved in innate and acquired immunity (YUAN et al, 2012). Since the 1970s, they have suggested that propolis's immunomodulatory activity is associated with macrophages activation and the increase in their phagocytic capacity (SCHELLER et al, 1977). The verum product administration resulted in a statistically significant decrease in the number of neutrophils and monocytes ( $p<0.05)$ in SBHPG compared to PG. Macrophages, neutrophils, and monocytes play an essential role in inflammatory processes. During pathogen-induced inflammation, neutrophils or monocytes/macrophages release reactive oxygen species (ROS) and nitric oxide (NO) and cytokines generate mediators of inflammation such as prostaglandins (PG) and leukotrienes (KRÓL et al, 1996). Overexpression of these cellular mediators causes acute or chronic inflammatory responses. Flavonoids and phenolic compounds, biologically active molecules in propolis, modulate the production of reactive oxygen (ROS), nitric oxide (NO) and inflammatory cytokines by monocytes/macrophages and neutrophils (SFORCIN, 2007; CHAN et al, 2013). The decrease in the number of neutrophils and monocytes could be due to the antiviral synergism between flavonoids and vitamin $\mathrm{C}$ inhibiting the viral load and decreasing the number of these white blood cells involved in the nonspecific immune response. These results are consistent with the results published by Preeti et al., which, in an in vivo study, reported a decrease in the number of neutrophils and monocytes in guinea pigs infected with Salmonella enterica and treated with propolis extract (2016). The verum product administration also had the effect of a slight increase in the number of lymphocytes $(p=0.05)$. Studies have shown that extracts rich in phenolic compounds and flavonoids also have an immunomodulatory effect on lymphocytes. Park et al. showed that treatment with standardized propolis extracts for CAPE directly or indirectly affects the number of immune cells, especially $\mathrm{T}$ cells. In vivo experiments in guinea pigs showed that propolis extracts stimulated $\mathrm{T}$ cell proliferation and IL-synthesis. 2, IL-4 and IFN- $\gamma$, but did not affect B lymphocyte count (PARK et al, 2004). The propolis extract of this supplement formula may lead to the $\mathrm{T}$ cells proliferation, cells that mediate the cellular immune response.

\section{Conclusion}

The nutritional supplement formula decreased the incidence of respiratory viruses infections and reduced the symptoms severity. Simultaneously, the immunomodulatory effect was manifested by a statistically significant reduction in the number of neutrophils and monocytes and an increase in the number of lymphocytes in the group that received the verum product. Although 
the number of study participants was relatively small, the results encourage further investigation into this formula's prophylactic effects against respiratory viruses. The number of infections has been small enough to draw definite conclusions, but the results are promising and deserve further research. Future studies should evaluate this nutritional supplement formula's prophylactic effect on many participants over a more extended period. Given that this supplement formula has reduced the severity of symptoms, future studies could also evaluate this formula's curative potential in case of infection with a respiratory virus.

\section{Acknowledgment} study.

I thank all the volunteers who participated in the

\section{Conflicts of Interest}

The authors declare that there are no conflicts of interest.

\section{References}

1. CHOI HJ, SONG JH, KWON DH. Quercetin 3-rhamnoside exerts antiinfluenza a virus activity in mice. Phytother. Res. 2012; 26, 462-464.

2. CHOI, HJ SONG, JH, PARK, KS, KWON DH. Inhibitory effects of quercetin 3-rhamnoside on influenza A virus replication. Eur. J. Pharm. Sci. 2009; 37, 329-333.

3. ROUSI A. The genus Hippophae L. A taxonomic study, Ann. Bot. Fennici. 1971; 8, 177-227.

4. YANG B, KALIMO KO, TAHVONEN RL, MATILLA LM et al. Effect of dietary supplementation with sea buckthorn (Hippophae" rhamnoides) seed and pulp oils on the fatty acid composition of skin glycerophospholipids of patients with atopic dermatitis. J. Nutr. Biochem. 2000; 11 (6), 338-340.

5. XU MY, SUN XX, TONG WX. Medical research and development of seabuckthorn (J). Hippophae. 1994; 7, 32-40.

6. SOLTUZU B. Cătina albă în fitoterapie. Ed. Univ. București, 2018.

7. MANYI-LOH CE, CLARKE AM AND NDIP RN. Detection of phytoconstituents in column fractions of n-hexane extract of Goldcrest honey exhibiting antiHelicobacter pylori activity. Arch. Med. Res. 2012; 43, 197-204.

8. MOLAN PC. Why honey is effective as a medicine. I. Its use in modern medicine. Bee World. 1999; 80, 80-92.

9. MORIYAMA M, HUGENTOBLER JW, IWASAKI A. Seasonality of Respiratory Viral Infections. Annu. Rev. Virol. 2020; 7:83-101.
10. PARASKEVIS D, KOSTAKI EG, MAGIORKINIS G, PANAYIOTAKOPOULOS G. et al. Full-genome evolutionary analysis of the novel corona virus (2019-nCoV) rejects the hypothesis of emergence as a result of a recent recombination event. Infect Genet Evol. 2020; 79:104212.

11. Institutul Național de Sănătate Publică, Centrul Naţional de Supraveghere și Control a Bolilor Transmisibile.

https://www.cnscbt.ro/index.php/analiza-cazuriconfirmate-covid19.

12. JACKSON G, DOWLING H, SPIESMAN I, BOAND A. Transmission of the common cold to volunteers under controlled conditions. Arch Intern Med. 1958; 101: 267-78.

13. TIITINEN K, HAKALA M, KALLIO H. Quality components of sea buckthorn (Hippophae rhamnoides) varieties. J. Agric Food Chem. 2005; 53, 1692-1699.

14. HEILSCHER K and LORBER S. Cold working process for obtaining clear juice sediment and oil from sea buckthorn berries and their use. GFR Patent DE 4431 395. Food Sci. Technol. Abstr. 1996; 6:1261.

15. MOHAMMED EA, AL-MOSA A, and BRIMA EI. Vitamin C Concentration in Acacia and Ziziphus Honey Samples from different Altitudes in Asir Region at the South Western Part of Saudi. PONTE International journal of sciences and research, 2018; 74(1): 1-15.

16. BOERU V, DEREVICI A. Some chemical and physical data on Romanian propolis. Apimondia "propolis", Bucharest. 1978; 19-26.

17. BIANCATELLI CRML, BERRILL M, CATRAVAS JD and MARIK P. Quercetin and Vitamin C: An Experimental, Synergistic Therapy for the Prevention and Treatment of SARS-CoV-2 Related Disease (COVID-19). Frontiers in Immunology. 2020; 11: 1451.

18. GUTZEIT D, BALEANU G, WINTERHALTER P, JERZ G. Vitamin C Content in Sea Buckthorn Berries (Hippophaë rhamnoides L.) and Related Products: A Kinetic Study on Storage Stability and the Determination of Processing Effects. Journal of food science. 2008; 73(9): 615-620.

19. DOBRINAS S, MATEI N, SOCEANU A, BIRGHILA S et al. Estimation of vitamin $\mathrm{C}$ and $\mathrm{Cd}, \mathrm{Cu}, \mathrm{Pb}$ content in honey and propolis, Scientific study \& research. 2006; 7(4):729-734.

20. COHEN HA, VARSANO I, KAHAN W, SARRELL EM et al. Effectiveness of an herbal preparation containing echinacea, propolis, and vitamin $\mathrm{C}$ in preventing respiratory tract infections in children: a randomized, double-blind, placebo-controlled, multicenter study. Arch Pediatr Adolesc Med. 2004; 158(3):217-21.

21. LARMO P, ALIN J, SALMINEN E, KALLIO H, TAHVONEN R. Effects of sea buckthorn berries on 
infections and inflammation: a double-blind, randomized, placebo-controlled trial. European Journal of Clinical Nutrition. 2008; 62, 1123-1130.

22. TURNER RB, FOWLER SL, BERG K. Treatment of the common cold with troxerutin. APMIS. 2004; 112, 605-611.

23. ARMSTRONG S. Covid-19: Tests on students are highly inaccurate, early findings show. BMJ. 2020; 371.

24. DESBIENS NA. In randomized controlled trials, should subjects in both placebo and drug groups be expected to guess that they are taking drug $50 \%$ of the time? Med Hypotheses. 2002; 59, 227-232.

25. YUAN J, LIU J, HU Y, FAN et al. The immunological activity of propolis flavonoids liposome on the immune respons. J Biol Macromol. 2012; 51(4): 400-5.

26. SCHELLER S, TUSTANOWSKI J, FELUS E, STOJKO A. Biological properties and clinical applications of propolis. VII. Investigation of the influence of ethanol extract of propolis (EEP) on cartilaginous regeneration. Arzneimittelforschun. 1977; 27:2142.

27. KRÓL W, CZUBA ZP, PIETSZ G, THREADGILL $\mathrm{MD}$ et al. Modulation of the cytotoxic activity of murine macrophages by flavones. Curr Top Biophys. 1996; 20:88-93.

28. SFORCIN JM. Propolis and the immune system: a review. J Ethnopharmacol. 2007; 113:1-14.

29. CHAN GC, CHEUNG KW, SZE DM. The immunomodulatory and anticancer properties of propolis. Clin Rev Allerg Immunol. 2013: 44:262-73.

30. KALIA P, KUMAR NR and HARJAI K. Effect of propolis extract on hematotoxicity and histological changes induced by salmonella enterica serovar typhimurium in balb/c mice. Arch Biol Sci. 2016; 68(2):385-391.

31. PARK JH, LEE JK, KIM HS, CHUNG ST et al. Immunomodulatory effect of caffeic acid phenethyl ester in Balb/c mice. Int Immunopharmacol. 2004; 4:429-36.

32. PUHAKKA T, PITKARANTA A, RUUSKANEN O. Common cold and its complications. Duodecim. 2000; 116:39-45. 